\title{
Developing library staff digital literacies
}

\author{
Dr Charles Inskip, Programme director, MA Library and Information Studies, \\ Department of Information Studies, University College London
}

\begin{abstract}
There are fundamental changes in the library and information profession caused by the widespread adoption of digital technology. Individuals, employers, professional associations and library schools all have a part to play in continuing staff development. The digital literacies or digital capabilities of staff across sectors are increasingly important in terms of service delivery and quality evaluation. This chapter examines the contextual perspectives of a selection of key associations in the UK and considers how these inform their delivery of digital literacies to their members. Self-directed development is also considered, suggesting that a combined top-down / bottom-up approach to staff development is likely to produce optimal results, not least because, without the resourcing provided by policy-driven outputs, grass roots initiatives are unsustainable.
\end{abstract}

\section{Introduction}

As the $21^{\text {st }}$ century progresses it has become increasingly apparent that the library and information profession's role needs to continually adapt to the dynamic context caused by the impact of digitisation. The development of the profession over the last century has reacted to regular changes in circumstances and ways of thinking, so this is nothing new (Abbott, 1988). While there are some obvious important stakeholders to be considered here: the individual, the employer, the professional association and the library school, there are others that have a key role to play in contributing to and supporting the development of librarians. In this chapter, we'll have a look at a variety of these stakeholders, and explore how they are supporting librarian development, focussing on digital literacies.

We'll look at some of the literature around the changing roles and consider the recent professional context. Then we'll examine some of the key drivers in library staff development, including the recent impact of the use of digital capability as a quality measurement. This chapter will provide an overview of the landscape and offer up some ideas about how librarians can contribute to their own and their colleagues' development of digital literacies.

A survey of UK Heads of Service undertaken by Society of College, National and University Libraries (SCONUL) (SCONUL, 2012) considered and explored six key capabilities derived from the JISC Seven elements of digital literacies model: ICT / computer literacy, information literacy, media literacy, communication and collaboration, digital scholarship, and learning skills. The survey findings demonstrated various levels of current expertise in these literacies and identified priorities in their development (Inskip, 2016). Also identified was a high level of support within the workplace for staff development, particularly with a role or sector-specific focus. Wider contributions from professional 
associations and library schools were considered by the participants to be of less importance than workplace delivery. This chapter builds on the SCONUL findings by exploring how digital literacies are conceived and considering the role of the librarian as a developer of these literacies in others.

\section{Digital literacies}

First of all, we need to clarify where we stand on the meaning of 'digital literacy' (or 'literacies'). There has been much discussion on defining this multi-faceted terminology through the literature (eg Bawden 2001, Pinto, Cordón, and Díaz 2010, Webber and Johnston 2017). While this discussion is essential, we will not be examining it in detail for now. However if you explore the literature, you will see how much it highlights the relational and contextual nature of these literacies. In other words, if there is so much discussion and so many different interpretations, then we need to recognise that there are multiple meanings depending on who is making that meaning, and what their context is. This constructivist approach to reality may be rather complex, and considered by some to be subjective, but if we understand the possibility of a kaleidoscopic view of truth then it makes inconsistencies easier to understand and accept. The use of the terms 'information literacy', 'digital literacy' and 'media literacy' appear to be converging: entering the three terms into Google Trends ${ }^{1}$ shows quite clearly that the use of 'digital literacy' as a search query is increasing, while 'media' shows a slow decline and 'information' is steeper - at the time of writing (according to Google's data) they all being used approximately equally in number.

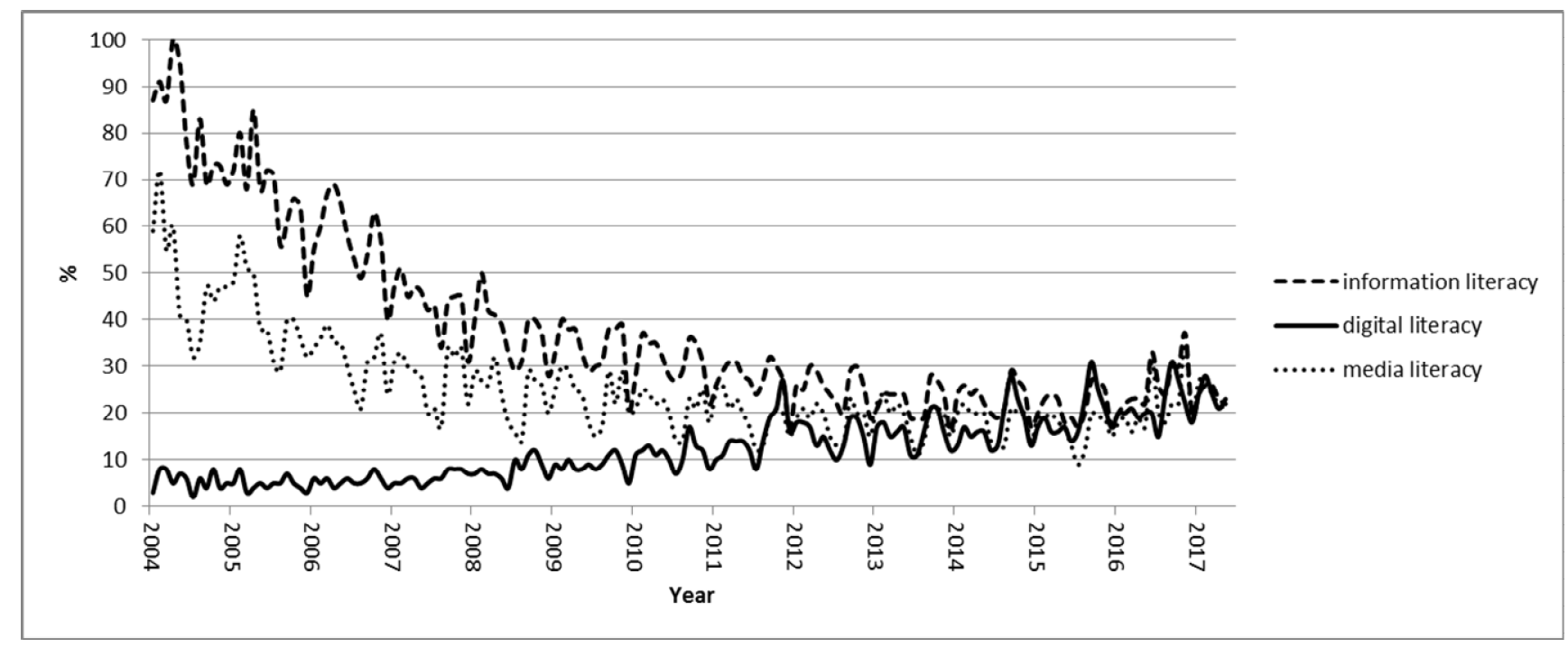

Figure 1 Google Trends - comparison of search terms 2004 - 2017

The following definition, aimed at primary and secondary school teachers, helps identify the centrality of technology as a supporting medium within this process:

"To be digitally literate is to have access to a broad range of practices and cultural resources that you are able to apply to digital tools. It is the ability to make and share meaning in different modes and formats; to create, collaborate and communicate effectively and to 
understand how and when digital technologies can best be used to support these processes." (Hague and Payton, 2010)

The European Parliament identifies 'digital competence' as one of the Eight Key Competences for Lifelong Learning:

"Digital competence involves the confident and critical use of Information Society Technology (IST) for work, leisure and communication. It is underpinned by basic skills in ICT: the use of computers to retrieve, assess, store, produce, present and exchange information, and to communicate and participate in collaborative networks via the Internet." (2006)

In her analysis of 15 digital competence frameworks, Anusca Ferrari synthesises a definition:

"Digital Competence is the set of knowledge, skills, attitudes, abilities, strategies and awareness that is required when using ICT and digital media to perform tasks; solve problems; communicate; manage information; behave in an ethical and responsible way; collaborate; create and share content and knowledge for work, leisure, participation, learning, socialising, empowerment and consumerism." (Ferrari et al., 2012)

The technologists' view is succinct; the British Computer Society (BCS), as part of their 'digital literacy for life' strategy, being quite specific:

"Digital literacy is about being able to make use of technologies to participate in and contribute to modern social, cultural, political and economic life." (BCS, 2017b).

This approach aligns with the other key technologist player in this arena, JISC, whose definition directly informs the BCS approach (JISC, 2014). Importantly, JISC go on to discuss the importance of going:

“...beyond functional IT skills to describe a richer set of digital behaviours, practices and identities. What it means to be digitally literate changes over time and across contexts, so digital literacies are essentially a set of academic and professional situated practices supported by diverse and changing technologies" (JISC, 2014) .

At the time, this definition referred to JISC's 'Seven Elements of Digital Literacies' model, which identified media literacy, communications and collaboration, career \& identity management, ICT literacy, learning skills, digital scholarship, and information literacy as discrete elements of digital literacy. The model was subsequently revised to become the 'Digital capability framework' (JISC, 2017). Here, ICT proficiency was situated at the heart, linking together information, data and media literacies, digital creation and problem solving and innovation, digital communication, collaboration and participation, and digital learning and development, all encompassed by digital identity and wellbeing. In the proposed structure of the BCS's draft qualification, the Technical Award in Digital Literacy, the JISC recommendation to go 'beyond the functional IT skills' seems to have been sidelined by BCS's technical mission, to close the digital skills gap. They aim to "provide learners with the ability to use technology creatively, efficiently and safely to live, learn and work in a digital society" (BCS, 2017a). There is some tension between realising the JISC vision of digital literacies becoming "academic and professional situated practices" through BCS's focus on an "ability to use technology". However, this is not an issue if we remind ourselves of the relational and contextual 
nature of whatever 'digital literacy' may be, and if we recognise that all stakeholders have a part to play.

So, if 'digital literacy' is about people participating in a digital society, or learners developing their technology competences, what does this have to do with librarians?

\section{Professional development}

As digitisation has impacted on the information world, it has equally impacted on the role and skills of the information professional (Missingham, 2006, Corrall, 2010, Arif and Mahmood, 2012, Cox and Corrall, 2013, Shahbazi and Hedayati, 2016). Although library schools are rising to this challenge, particularly in relation to digital libraries (Bawden et al., 2005, Tammaro, 2007), a continuing developmental approach is needed if we are to successfully address the issues caused by the dynamic changes in professional context and keep up-to-date (Emanuel, 2013, Corcoran and McGuinness, 2014, Martzoukou and Elliott, 2016, Tattersall, 2017). It is asserted by Cooke that "librarians need to be as savvy as their clients" (2012) because the ethics of the profession demand it (Hurych, 2002) as the shifting nature of the information context means competences require constant development (Weingand, 2000). In terms of digital literacy, there is also a need for librarians to address disintermediation through the wider use of internet technologies such as podcasts and social media (Brabazon, 2014). It has been suggested that continuing professional development (CPD) not only contributes to professional but also generic attributes such as confidence and communications (Hamid and Soroya, 2017). Although CPD is not globally formally required or mandated (Cooke and Teichmann, 2012, Thomas et al., 2010), in the UK it is strongly encouraged through the Chartered Institute of Library and Information Professionals' (CILIP) Professional registration scheme. ${ }^{2}$ This scheme, which is supported by an online learning programme and a mentored reflective portfolio, is designed to demonstrate participants' up-to-date skills and knowledge, and successful completion is required for inclusion in the professional Register of Practitioners (although exclusion from the register does not prevent one from practising (Cannon, 2017)). Regular revalidation is encouraged but not mandated by the association, although employers may require evidence of CPD at annual appraisal. Registration is informed and assessed through application of the Professional Knowledge and Skills Base (PKSB), which is also used to accredit library school library and information studies programmes. This over-arching application of criteria in the UK, linking learning providers' delivery with individual and employer-driven staff development allows the association to guide a consistent view of competencies.

\section{Through a digital lens}

SCONUL's 'Seven Pillars' model prioritises information literacy and encompasses digital and other literacies, attitudes and behaviours, many of which are also included in the more recent JISC model. The SCONUL model was developed from the viewpoint of members of the professional association for UK national, university and college libraries and its' 'informationist' (rather than 'technologist') approach here is clearly established through the set of pillars, which are named: Identify, Scope, Plan, Gather, Evaluate, Manage, Present (SCONUL, 2011). An important recent development of the model was the addition of a digital lens (SCONUL, 2013). In addition to demonstrating SCONUL's recognition of the role of librarians in supporting and developing digital literacies, this also met the

\footnotetext{
${ }^{2}$ https://www.cilip.org.uk/cilip/jobs-careers/professional-registration/what-level-right-you
} 
revised core model aims, which were to make the seemingly inflexible 'pillars' more adaptable to local and professional contexts (other lenses were to follow, including health and graduate employability (SCONUL, 2017)). A brief comparison between the SCONUL digital lens and the BCS draft curriculum suggests that there is a link between the views of the informationists and the technologists. The SCONUL digital lens identifies 'understanding' of various concepts and 'ability' to use, manage, identify or develop (for example) skills or tools related to each of the pillars. This approach sits more readily with the JISC view although pragmatically recognising the importance of skills development within a wider framework, which also includes understanding, behaviour and attitudes. While the Seven Pillars are predominantly designed (and widely used) to support students in UK Higher Education, a secondary purpose is to contribute to the development of librarian proficiencies, as a self-evaluative continuing development tool.

JISC helpfully recently published a Library and information professional profile aligned to their digital capabilities framework, alongside other profiles (teacher, learning technologist, leader, researcher) (Beetham, 2017). The profile maps the framework to the CILIP PKSB (CILIP, 2013) and aims to act as an evaluative tool for staff development, almost as a digital literacy lens on the PKSB. Each of the six elements are unpacked, looking at how librarians' practice would relate to the element and, importantly, how their practice would relate to the wider institution. This contextual analysis supports the potential use of the profile as a staff development tool and, particularly, as an advocacy tool for evaluating impact. (Although it is too early to tell how this is being received, case studies from the project development team suggest a 'whole organisation' approach is being readily adopted by some institutions ${ }^{3}$.) The purpose of these two criteria links strongly to the strategic use of the digital capabilities framework by the Quality Assurance Agency (QAA) in their recent assessment theme of digital literacy (QAA, 2014), which swiftly drew the attention of learning provider quality assurance offices to this concept. Through activities such as embedding their framework into the QAA, providing a mapping to the CILIP PKSB and informing the development of BCS' proposed qualification it is clear that JISC are engaging at a high level with a range of important stakeholders. This engagement suggests a continuing widespread adoption of their framework, which will continue to raise the profile of digital literacy amongst government, education providers and industry.

JISC's examination of librarian roles and competences through a digital literacy lens provides some useful guidance relating to these literacies, identifying skills relating to each element and how the library and information professional contributes to their organisation through the application of these skills. For example, under 'digital learning and development', which maps to the PKSB's Literacies and learning, we might:

"Contribute to curriculum development e.g. embedding of information literacies.

Contribute to researcher development e.g. around digital scholarship.

Create digital learning materials independently or working with others (e.g. on information and library topics), ensuring they are fully accessible."

This means we are likely to:

\footnotetext{
${ }^{3}$ https://www.jisc.ac.uk/rd/projects/building-digital-capability
} 
"Contribute to the development of online learning and online courses.

Contribute to the use of learning and research technologies.

Contribute to the development of the library as a space of (formal and informal) learning. Meet the information literacy learning needs of the whole organisation, e.g. for digital information searching, discovery, interpretation, critical evaluation, managing, sharing and disseminating."

This 'contributing' role recognises the reality of teamworking across service and faculty departments which is integral to academic librarianship. Breaking each element into skills and contributions helps to situate the guide which may be helpful in the workplace as part of a toolkit, as a development and appraisal tool along with the PKSB.

For those outside further and higher education, the Society of Chief Librarians (SCL) have introduced a sector-wide training programme for public library staff. The Universal Offers strategy, includes the Information Offer aims:

"To bring together government and non-government sources of information, which have been researched by information professionals in public libraries, giving the customer a level of quality assurance.

To ensure that our staff and volunteers are continually developing their skills to provide the help some people need to access information and services online" (SCL, 2017b)

And the Digital Offer states that:

"As a baseline every public library service should provide: Free internet access (for a minimum period of time); Clear and accessible online information about library services; Staff trained to help customers access digital information" (SCL, 2017a)

The training programme, "Digital Information Skills for Library Workforce" (SCL, 2017c), identifies key learning outcomes, such as "fluently navigate and use national and local government information sites" through a set of online modules. Despite some technical problems in the delivery of this ambitious programme, it was reported that the nationally coordinated approach made a significant contribution in an increase of staff confidence, particularly in the use of government resources, and in staff feeling more able to help library users (Moorcroft \& Myers, 2015).

These top-down initiatives are mirrored by numerous grass roots development opportunities such as TeachMeets, informal peer-to-peer networks within and between workplaces and other self- and community-motivated development approaches. Although it is not within the scope of this chapter to explore these in detail it is very important to recognise the value of the motivated practitioner in the self-development process. Bottom-up initiatives and those led by the supportive employer are widely used and engender involvement by the community through their participation in organising and running these as well as taking part in them. The UK professional association also supports CPD through their mentored Chartership scheme, where progress is evaluated within the framework of the Professional Knowledge and Skills Base (PKSB) (CILIP, 2013). 'Literacies and learning', which include information literacy, are considered a professional competence within the PKSB. The CILIP Information Literacy Group (ILG) also plays a key role in leading and encouraging staff development activities and advocating for information (and digital) literacies. They publish the peer-reviewed 
Journal of Information Literacy, organise the LILAC international conference and fund practitioner research in order to contribute to the development of good information literacy practice in the profession.

\section{Conclusions}

Recognition by CILIP's PKSB, JISC's digital capability framework and profile mapping, the BCS draft curriculum and SCL's training programme demonstrates quite clearly that there are a range of offers available for continuing professional development specifically in terms of digital literacies for the profession. The value of these contributions in the delivery of quality-assurance based interventions and guidance is in the raising of awareness at policy-maker level. Although the huge impact of grass roots efforts cannot be denied, without recognition at the top they are sustainable only due to the efforts of the communities and the individuals concerned. Success is most likely to come from a combined approach, with high-level policy and grassroots efforts working together. If information literacy is recognised formally not only within the library and information studies curriculum but also in school, Further, and Higher Education curricula then the efforts of library and information professionals in developing their digital literacies to effectively support and educate users will not be in vain. It is recommended that individuals reflect on their digital (and information) literacies and capabilities and recognise that continuous development can be supported by peers as well as by employers and formal stakeholder communities such as professional associations, special interest groups and library schools. A holistic approach, which encourages inter-disciplinary and multi-service conversations, would help to situate the profession within the wider context and reinforce the value and role of the librarian in a digitally capable world.

\section{References}

Abbott, A. D. (1988) The system of professions : an essay on the division of expert labor. Chicago ; London: University of Chicago Press.

Arif, M. and Mahmood, K. (2012) 'The changing role of librarians in the digital world Adoption of Web 2.0 technologies by Pakistani librarians', Electronic Library, 30(4), pp. 469-479.

Bawden, D. 2001. "Information and digital literacies: A review of concepts." Journal of Documentation 57 (2), pp. 218-259. doi: 10.1108/eum0000000007083.

Bawden, D., Vilar, P. and Zabukovec, V. (2005) 'Education and training for digital librarians - A Slovenia/UK comparison', Aslib Proceedings, 57(1), pp. 85-98.

BCS (2017a) BCS Level 1/2 Technical Award in Digital Literacy / IT user qualifications / Qualifications and Certifications. Available at: http://www.bcs.org/category/19022 (Accessed: 16th June 2017).

BCS (2017b) Digital literacy for life. Available at: http://www.bcs.org/category/17853 (Accessed: 16th June 2017).

Beetham, H. (2017) Digital capability profiles for different roles / Jisc digital capability codesign challenge blog. Available at: https://digitalcapability.jiscinvolve.org/wp/2017/03/08/digital-capability-profiles-fordifferent-roles/ (Accessed: 17th June 2017).

Brabazon, T. (2014) 'The disintermediated librarian and a reintermediated future', Australian Library Journal, 63(3), pp. 191-205.

Cannon, P. (2017) 'A review of professionalism within LIS', Library Management, 38(2/3), pp. 142-152.

CILIP (2013) Using the Professional Knowledge and Skills Base. Available at: http://www.cilip.org.uk/careers/professional-knowledge-skills-base/using-professional-knowledgeskills-base (Accessed: 17th June 2017).

Cooke, N. A. (2012) 'Professional development 2.0 for librarians: developing an online personal learning network (PLN)', Library Hi Tech News, 29(3), pp. 1-9.

Cooke, N. A. and Teichmann, J. J. (2012) 'Keeping current', Instructional Strategies and Techniques for Information Professionals: Chandos Publishing, pp. 99-116. 
Corcoran, M. and McGuinness, C. (2014) 'Keeping ahead of the curve: Academic librarians and continuing professional development in Ireland', Library Management, 35(3), pp. 175-198.

Corrall, S. (2010) 'Educating the Academic Librarian as a Blended Professional: A Review and Case Study', Library Management, 31(8-9), pp. 567-593.

Cox, A. M. and Corrall, S. (2013) 'Evolving academic library specialties', Journal of the American Society for Information Science and Technology, 64(8), pp. 1526-1542.

Emanuel, J. (2013) 'Digital Native Librarians, Technology Skills, and Their Relationship with Technology', Information Technology and Libraries, 32(3), pp. 20-33.

Ferrari, A., Punie, Y. and Redecker, C. (2012) 'Understanding Digital Competence in the 21st Century: An Analysis of Current Frameworks', in Ravenscroft, A., Lindstaedt, S., Kloos, C.D. \& Hernández-Leo, D. (eds.) 21st Century Learning for 21st Century Skills: 7th European Conference of Technology Enhanced Learning, EC-TEL 2012, Saarbrücken, Germany, September 18-21, 2012. Proceedings. Berlin, Heidelberg: Springer Berlin Heidelberg, pp. 79-92.

Hague, C. and Payton, S. (2010) Digital literacy across the curriculum. Bristol: Bristol : Futurelab.

Hamid, A. and Soroya, M. S. (2017) 'Continuing education for LIS professionals: why', Library Review, 66(1-2), pp. 83-89.

Hobbs, R. (2010) Digital and Media Literacy: A Plan of Action: Knight Foundation. Available at: https://knightfoundation.org/reports/digital-and-media-literacy-plan-action (Accessed: 25th June 2017).

Hurych, J. (2002) 'Continuing professional education as an ethical issue', in Ward, P.L. (ed.) Continuing Professional Education for the Information Society: The Fifth World Conference of Continuing Professional Education for the Library and Information Science Professions: Vol. 100: IFLA, pp. 256263.

Inskip, C. (2016) 'Novice to Expert: developing digitally capable librarians', in Mackenzie, A. \& Martin, L. (eds.) Developing digital scholarship: emerging practices in academic libraries. London: Facet, pp. 59-75.

JISC (2014) Developing digital literacies: JISC. Available at: https://www.jisc.ac.uk/guides/developing-digitalliteracies (Accessed: 8th June 2017).

JISC (2017) Building digital capability. Available at: https://www.jisc.ac.uk/rd/projects/building-digitalcapability (Accessed: 16th June 2017).

Martzoukou, K. and Elliott, J. (2016) 'The development of digital literacy and inclusion skills of public librarians', Communications in Information Literacy, 10(1), pp. 99-115.

Missingham, R. (2006) 'Library and information science: Skills for twenty-first century professionals', Library Management, 27(4/5), pp. 257-268.

Moorcroft, S. \& Myers, A. (2015) Evaluation of the Public Library Universal Information Offer workforce development programme: Supporting Digital Access to Information and Services. Available at http://goscl.com/scl-continues-to-raise-digital-skills-and-leadership-standards/ (Accessed 29 ${ }^{\text {th }}$ Sept 2017).

Parliament, E. (2006) Recommendation of the European Parliament and of the Council of 18 December 2006 on key competences for lifelong learning (2006/962/EC). Available at: http://eur-lex.europa.eu/legalcontent/EN/TXT/HTML/?uri=CELEX:32006H0962\&from=EN (Accessed: 1st July 2017).

Pinto, M., J. A. Cordón, and R. G. Díaz. 2010. "Thirty years of information literacy (1977-2007): A terminological, conceptual and statistical analysis." Journal of Librarianship and Information Science 42 (1):3-19. doi: 10.1177/0961000609345091.

QAA (2014) The Quality Assurance Agency for Higher Education (QAA): The Quality Assurance Agency for Higher Education (QAA). Available at: http://www.qaa.ac.uk/publications/information-andguidance/publication?PubID=2859\#.WUVOg-vyvIU (Accessed: 17th June 2017).

SCL (2017a) Universal Digital Offer. Available at: http://goscl.com/universal-offers/digital-offer/ (Accessed: 25th June 2017).

SCL (2017b) Universal Information Offer. Available at: http://goscl.com/universal-offers/information-offer/ (Accessed: 25th June 2017).

SCL (2017c) Workforce Development E-learning Modules. Available at: http://goscl.com/training/ (Accessed: 25th June 2017).

SCONUL (2011) The SCONUL Seven Pillars of Information Literacy: core model for Higher Education. Available at: https://www.sconul.ac.uk/sites/default/files/documents/coremodel.pdf (Accessed: 29th June 2017). 
SCONUL (2012) SCONUL Baseline summary. Available at: http://jiscdesignstudio.pbworks.com/w/page/50824902/SCONUL\%20Baseline\%20summary (Accessed: 25th June 2017).

SCONUL (2013) The SCONUL 7 Pillars of Information Literacy through a Digital Literacy 'lens'. Available at: https://www.sconul.ac.uk/sites/default/files/documents/Digital Lens.pdf (Accessed: 29th June 2017).

SCONUL (2017) Seven Pillars of Information Literacy resources. Available at: https://www.sconul.ac.uk/page/seven-pillars-of-information-literacy (Accessed: 29th June 2017).

Shahbazi, R. and Hedayati, A. (2016) 'Identifying Digital Librarian Competencies According to the Analysis of Newly Emerging IT-based LIS Jobs in 2013', Journal of Academic Librarianship, 42(5), pp. 542-550.

Tammaro, A. M. (2007) 'A curriculum for digital librarians: a reflection on the European debate', New Library World, 108(5/6), pp. 229-246.

Tattersall, A. (2017) 'Supporting the research feedback loop', Performance Measurement and Metrics, 18(1), pp. 28-37.

Thomas, V. K., Satpathi, C. and Satpathi, J. N. (2010) 'Emerging challenges in academic librarianship and role of library associations in professional updating', Library Management, 31(8/9), pp. 594-609.

Webber, Sheila, and Bill Johnston. 2017. "Information literacy: conceptions, context and the formation of a discipline." Journal of Information Literacy 11 (1):156-183. doi: 10.11645/11.1.2205.

Weingand, D. E. (2000) 'Describing the Elephant: What Is Continuing Professional Education?', IFLA Journal, 26(3), pp. 198-202. 